\title{
Response of Daylily (Hemerocallis hybridus cv. 'Stella de oro') to saline water irrigation in two coastal saline soils
}

Xiaobin $\mathrm{Li}^{1,2}$, Yaohu Kang ${ }^{1, *}$, Shuqin Wan ${ }^{1}$, Jiachong $\mathrm{Xu}^{1,2}, \mathrm{Na} \mathrm{Li}^{1,2}$

${ }^{1}$ Key Laboratory of Water Cycle and Related Land Surface Processes, Institute of Geographic Sciences and Natural Resources Research, Chinese Academy of Sciences, Beijing 100101, China

${ }^{2}$ University of Chinese Academy of Sciences, Beijing 100049, China

\author{
* Corresponding author at: Key Laboratory of Water Cycle and Related Land Surface Processes, \\ Institute of Geographic Sciences and Natural Resources Research, Chinese Academy of Sciences, 11 A \\ Datun Road, Anwai, Beijing 100101, China. \\ Tel: +8610 64856516; Fax: +861064856516. \\ E-mail address: kangyh@igsnrr.ac.cn.
}

\begin{abstract}
In order to evaluate the effects of irrigation water salinity, applied by drip irrigation, on Daylily (Hemerocallis hybridus cv. 'Stella de oro') growth and soil salinity, a three-year experiment was conducted in coastal saline region in Caofeidian District East China during 2013-2015 in two soils (sandy loam and silt). Five water salinity treatments were used with saline water at electrical conductivity $\left(\mathrm{EC}_{\mathrm{iw}}\right)$ of $0.8,3.1,4.7,6.3$, and $7.8 \mathrm{dS} / \mathrm{m}$. The original soil salinity expressed as electrical conductivity of the saturation paste extract $\left(\mathrm{EC}_{\mathrm{e}}\right)$ was $27-30 \mathrm{dS} / \mathrm{m}$ in the $0-95 \mathrm{~cm}$ depth. Results showed that drip-irrigation was effective in salt leaching. The average values of soil $\mathrm{EC}_{\mathrm{e}}$ for five treatments were 1-4 and 2-6 dS/m in $0-35 \mathrm{~cm}$ soil profiles of sandy loam and silt soils, respectively, after 18 months with drip irrigation. In 2014-2015, the survival rates were all >93\% when irrigated with saline water at $<7.8 \mathrm{dS} / \mathrm{m}$ for both saline soils. The survival rate and dry mass decreased by $0.63 \%$ and $17.14 \%$ for each unit of EC increase in the irrigation water in sandy loam saline soil, and the corresponding values were $0.70 \%$ and $25.63 \%$ in silt saline soil. This study implied that Daylily is a suitable plant in landscape construction of coastal saline soils using drip-irrigation at $\mathrm{EC}_{\mathrm{iw}}<7.8 \mathrm{dS} / \mathrm{m}$.
\end{abstract}


Keywords Daylily, salinity, Sandy loam, Silt, Survival rate, Dry mass

\section{Introduction}

In China, with the rapid development of industrialization and urbanization in coastal regions, vegetation landscape construction has become a major issue and has attracted increasing awareness (Chen et al. 2015; Li et al. 2015a, b). However, it is still a challenging work as there are many saline soils and saline water around the development zone. Most of these soils cannot be initially used for landscape plants due to high levels of salt. Many methods including engineering, mechanical, chemical and biological have been used for reclamation of the coastal saline wasteland in attempts to improve the landscape, but were found ineffective due to high cost or fresh water limitation. In recent years, a regulatory method was scheduled for drip-irrigation to control the soil matric potential (SMP) and was effective in reclamation of very severely coastal saline soils, and an SMP higher above $-5 \mathrm{kPa}$ at 20 cm depth under the emitter could be used as an indicator in the reclamation (Sun et al., 2012, 2013). The method has been successfully applied to the shrub plant (Chen et al., 2015; Li et al., 2015a,b,c). In order to extend the variety of plant types to construct a better and attractive landscape in coastal saline soils, and also extend the application of the proposed reclamation method and display its popularization, further studies are needed concerning salt tolerance of common landscape plants.

Daylily (Hemerocallis hybridus cv. 'Stella de oro') is a perennial flower and important landscaping material with good aesthetic appeal and long flowering period. It does not need extensive management, and can endure cold, hot, drought and other harsh environments. As kind of cover plant and salt-tolerant plant, Daylily has been widely applied in garden and road greening in landscape construction of coastal saline soil with freshwater irrigation (Mo. 2011). However, supplies of fresh water are already low in most coastal regions, and non-conventional water resources such as saline water, brackish ground water and treated wastewater are alternatives to fresh water resources (Rhoades et al. 1988). Saline water, rich in coastal regions, has been successfully used for irrigating landscape plants (Li et al. 2015a, b and d), and then is an ideal alternative for irrigation. Unfortunately, there is a dearth of information on Daylily subjected to salinity in field soil irrigated with saline water, and the suitable irrigation water salinity ranges were still unknown.

In this study, Daylily was planted in coastal regions with very severely sandy loam and silt saline 
soils, and received irrigation water at five levels of salinity using drip-irrigation. The aim of the study was to test the responses of Daylily to saline water irrigation when grown in coastal saline soils and make out the suitable irrigation water salinity ranges.

\section{Materials and methods}

\subsection{Site description}

Field experiments were conducted during 2013-2015 on coastal saline land in the Industrial Zone $\left(39^{\circ} 03^{\prime} \mathrm{N}, 118^{\circ} 48^{\prime} \mathrm{E}\right)$ and the International Eco-City $\left(39^{\circ} 20^{\prime} \mathrm{N}, 118^{\circ} 54^{\prime} \mathrm{E}\right)$ of Caofeidian District in the south of Tangshan city, east China, and north of Bohai Gulf which borders the Pacific Ocean. The station has a typical semi-humid monsoon climate with annual precipitation of approximately 550-580 $\mathrm{mm}$, mostly during June-September. The $\mathrm{EC}_{\mathrm{e}}$ and sodium adsorption rate (SAR) of the non-reclamation saline soils at a depth of $95 \mathrm{~cm}$ were $27-30 \mathrm{dS} / \mathrm{m}$ and 50-59 $(\mathrm{mmol} / \mathrm{L})^{0.5}$, respectively. The soils were silt in the Eco-City and sandy loam in the Industrial Zone based on soil classification standard of USDA. The initial soil texture, soil bulk density, $\mathrm{EC}_{\mathrm{e}}, \mathrm{pH}$ and $\mathrm{SAR}$ are shown in Table 1.

\subsection{Plot layout and irrigation}

In this study, soil was prepared for gravel-sand layer treatment as described in Li et al (2015a, b). That is soil was removed to a depth of $100 \mathrm{~cm}$ and a $15-\mathrm{cm}$ thick gravel layer was laid in the bottom and then covered with a 5-cm thick layer of sand - with native soil placed back above the sand (Fig. 1). A rotary tiller was used to break clay blocks and oyster shell of the soil to increase soil infiltration. Daylily was directly planted in 8 June of 2013 and 17 July of 2013 in silt and sandy loam saline soils, respectively, and received irrigation water at five levels $(0.8,3.1,4.7,6.3$ and $7.8 \mathrm{dS} / \mathrm{m})$ of salinity, with saline water composed by mixing fresh well-water and highly saline shallow-groundwater in different proportions. Each treatment included one plot with $3.0 \mathrm{~m} \times 3.0 \mathrm{~m}$, and each plot consisted of four raised $(15 \mathrm{~cm})$ beds. The raised bed was $0.3 \mathrm{~m}$ wide and $3.0 \mathrm{~m}$ long with $0.8 \mathrm{~m}$ between bed centers (Fig. 1). There are two rows of Daylily in each bed and a total of 72 strains of Daylily were planted in each plot with a spacing of $0.2 \mathrm{~m} \times 0.3 \mathrm{~m}$.

Each irrigation water salinity level had a separate gravity drip-irrigation system consisting of a tank (200 L) and 4 drip tubes. The tank was installed at $0.8 \mathrm{~m}$ above the ground to contain irrigation water. Drip tubes with $0.2-\mathrm{m}$ (in sandy loam soil) and $0.3-\mathrm{m}$ (in silt soil) emitter intervals were placed in the center of the beds. One vacuum gauge tensiometer was installed $0.2 \mathrm{~m}$ directly underneath one emitter located in the center of the plot for each treatment. The tensiometers were observed twice daily (at 8:00 
and 18:00h), and irrigation was applied when the reading value of tensiometers exceeded the target SMP value. Planting pattern, soil treatment and samplings distributions were shown in Fig. 1.

Irrigation water management was the same as described in $\mathrm{Li}$ et al. (2015a, b). Irrigation time was divided into two stages. The first stage was enhanced salt leaching. The second stage was water and salt regulation. Irrigation started based on soil matric potential (SMP). The target SMP value was greater than the corresponding value of SMP for field capacity in the early time, to cause a vertical downward soil water potential gradient which benefited salt leaching. Based on the experimental results of Sun et al. $(2012,2013)$, we set the SMP threshold at $-5 \mathrm{kPa}$ when the herbaceous plants were transplanted, and $-10 \mathrm{kPa}$ in the second year and $-13 \mathrm{kPa}$ in the third year combining with saving-water and soil salinity environment. The amount of water for each irrigation event was $6 \mathrm{~mm}$ in both soils when SMP reached the threshold value.

Irrigation started from the planting time of Daylily in 2013 and finished in 5 November of 2015. On 21-24 November of each year, $24 \mathrm{~mm}$ of freshwater irrigation was applied to each treatment and then irrigation was terminated until April due to the onset of winter. On 6-8 April of each year, $24 \mathrm{~mm}$ of freshwater irrigation was applied to each treatment to provide a suitable soil moisture environment for plant sprouting in spring, and then the irrigation begun.

\subsection{Observation and measurements}

The number of surviving plants was counted in 2013-2015. The shoot biomass of plants (three plants per treatment) was measured at the end of 2014. Soil cores were obtained from each plot using an auger ( $2.0 \mathrm{~cm}$ diameter, $15 \mathrm{~cm}$ high) before transplanting (8 June and 17 July in 2013 in silt and sandy loam soils, respectively.) and on November 2014. The samples were obtained at $0,10,20,30$ and $40 \mathrm{~cm}$ from the emitters. Soil samplings distribution was shown in Fig. 1.

All soil samples were air-dried and passed through a 1-mm sieve. Soluble salt estimates, soluble cations and soil $\mathrm{pH}$ were based on extracts of saturated soil. The concentration of soluble cations was determined using inductively coupled plasma spectrometry (Optima 5300DV, USA). The EC and pH were determined using a conductivity meter (DDS-11A, REX, Shanghai) and a pH meter (PHS-3C, REX, Shanghai), respectively. The SAR of the saturated paste extract was calculated as follows (Rhoades et al. 1992): 


$$
\mathrm{SAR}=\frac{\left[\mathrm{Na}^{+}\right]}{\left(\left[\mathrm{Ca}^{2+}\right]+\left[\mathrm{Mg}^{2+}\right]\right)^{0.5}}
$$

where the concentration of each cation is in $\mathrm{mmol} / \mathrm{L}$.

In this experiment, average $\mathrm{EC}_{\mathrm{e}}$ values within the whole soil profile were integrated to account for both spatial and temporal variations. The average values of $\mathrm{EC}_{\mathrm{e}}$ in the soil profile were calculated as follows (Dou et al. 2011):

$$
\mathrm{EC}_{\mathrm{e}}(t)=\frac{\sum_{j, k}^{n, m} \mathrm{EC}_{\mathrm{e}}(t, j, k) \times \mathrm{S}(j, k)}{\sum_{j, k}^{n, m} \mathrm{~S}(j, k)}
$$

where $t$ represents the time at which soil samples were obtained; $j$ the distances from the emitter where soil samples were attained; $k$ the depths of soil samples and $\mathrm{S}(j, k)$ the depth interval of the soil sample.

\subsection{Statistical analyses}

One empirical function was used to describe the survival rate and dry matter production of Daylily while subject to increasing salinity levels of irrigation water. Model is as follows:

$$
P I r=100-P I d\left(E C_{i w}-E C_{t}\right)
$$

where PIr is the relative plant index (actual plant index at the given salinity level divided by plant index with fresh water or low saline water), $\mathrm{EC}_{\mathrm{iw}}$ represents the irrigation water salinity ( $\mathrm{EC}$ of the irrigation water, $\mathrm{dS} / \mathrm{m}$ ), $\mathrm{EC}_{\mathrm{t}}$ is the threshold salinity level (TSL) (the maximum allowable salinity that does not reduce plant index measurably below that of a non-saline condition or irrigated with fresh water or low saline water, $\mathrm{dS} / \mathrm{m}$ ), and PId is the plant index decrease per unit of salinity increase beyond the threshold.

All data gathered in the research were recorded and classified in Microsoft Office Excel 2007. Analyses of variance (ANOVA) were carried out by SPSS 16.0 statistical software (SPSS Inc., IL, USA). The significance of the variables effect was examined by one-way ANOVA. Plant survival rates and shoot dry mass were evaluated statistically by trend analysis. Figures were created using Origin 8.0 (Origin Lab Inc., MA, USA).

\section{Results and discussion}




\subsection{Rainfall and irrigation}

During the experimental period, the total rainfall was 410,416 and $565 \mathrm{~mm}$, and the average amounts of irrigation were 288, 320 and $181 \mathrm{~mm}$ in 2013-2015 in the Industrial Zone (Table 2), respectively. The corresponding values of rainfall were 434,450 and $370 \mathrm{~mm}$, and amounts of irrigation were 326, 490 and $346 \mathrm{~mm}$ in the Eco-City, respectively. The irrigation amounts decreased with year in the same period (Jun/Jul-Nov), and this was mainly because that the SMP threshold value was controlled lower with year.

\subsection{Salt leaching}

Before transplanting of Daylily, the average $\mathrm{EC}_{\mathrm{e}}$ values in the 0-35 and 0-95 $\mathrm{cm}$ soil profiles were 27.47 and $27.57 \mathrm{dS} / \mathrm{m}$ in sandy loam soil, the corresponding values were 28.68 and $27.79 \mathrm{dS} / \mathrm{m}$ in silt soil. After nearly 18 months of drip-irrigation with saline water, soil salinity decreased significantly in both sandy loam and silt soils. In sandy loam soil, the average $\mathrm{EC}_{\mathrm{e}}$ values were 1-4 and 1-5 dS/m in the 0-35 and 0-95 cm soil profiles for five treatments (Fig. 2a), respectively, with saline soil becoming mildly saline (4-8 dS/m) or even non-saline $(<4 \mathrm{dS} / \mathrm{m})$. In silt soil, the average $\mathrm{EC}_{\mathrm{e}}$ values were 2-6 and $4-8 \mathrm{dS} / \mathrm{m}$ in the $0-35$ and $0-95 \mathrm{~cm}$ soil profiles (Fig. $2 \mathrm{~b}$ ), respectively, with saline soil becoming mildly saline except for at $\mathrm{EC}_{\mathrm{iw}}=0.8 \mathrm{dS} / \mathrm{m}$ in $0-35 \mathrm{~cm}$ soil profile.

Better salt leaching occurred in sandy loam soil than in silt soil, and the difference in soil $\mathrm{EC}_{\mathrm{e}}$ between 0-35 and 0-95 cm soil profiles were larger in silt soil than in sandy loam soil (Fig. 2). This could be attributed to the better soil infiltration in sandy loam soil (Li et al. 2015c). In the present study, salt leaching effects decreased with irrigation water salinity increasing (Fig. 2), which was consistent with other plants reported in the studies of Li et al. (2015a, b, d). In the present study, it was further proved that drip-irrigation is effective in reclamation of saline soils, with the very severely saline soils becoming mildly saline or even non-saline as planting age increases.

\subsection{Survival rate and dry mass}

The data of plant survival rate and shoot dry mass of Daylily for different treatments during the experiment and the trend analysis are shown in Table 3 and Fig. 3. Many studies reported that plant growth and dry mass production were affected by salinity, which has been confirmed in crops and other plants (Li et al, 2015b). In this study, the survival rates of Daylily decreased with irrigation water 
salinity increasing in 2015 and with year (Table 3 and Fig. 3a), and it were higher > 93\% in 2014 and 2015 in both soils (Table 3), which confirmed that daylily was a salt tolerant herbaceous plant (Ding et al. 2015). Slight higher survival rates occurred in silt soil than in sandy loam soil (Table 3), and this may be due to drought occurring more easily in sandy loam soil and thus enhance the effect of salinity on plant growth ( $\mathrm{Li}$ et al. 2016). Shoot dry mass showed similar trends in both soils with increasing first, and then decreased (Fig. 3b). When $\mathrm{EC}_{\mathrm{iw}}$ was higher $>6.3 \mathrm{dS} / \mathrm{m}$, shoot dry mass decreased significantly (Table 3 and Fig. 3b). Shoot dry mass values were higher in sandy loam than in silt soils (Table 3), and this is likely related with the plant growth habits that Daylily adapted to sandy loam soil well. Comparing with survival rate and shoot dry mass, it indicated that plant growth of Daylily was more sensitive than its survival to salt under higher salinity.

\subsection{Salt tolerance threshold}

One model was used to evaluate the effect of saline water irrigation on survival rate and dry weight (Fig. 4). The TSL value of Daylily was $1.50 \mathrm{dS} / \mathrm{m}$ in sandy loam soil according to analysis of the linear relationship between $\mathrm{EC}_{\mathrm{iw}}$ and survival rate; and the survival rate decreased by $0.63 \%$ for each unit of EC increase in irrigation water. The corresponding values were $2.50 \mathrm{dS} / \mathrm{m}$ and $0.70 \%$ in silt soil. Slight higher TSL occurred in silt soil than in sandy loam soil, likely also due to that drought occurred more easily in sandy loam soil and thus it enhanced the effect of salinity on survival.

Analysis of the linear relationship between dry weight and $\mathrm{EC}_{\mathrm{iw}}$ showed that the TSL value of Daylily was $4.34 \mathrm{dS} / \mathrm{m}$, and dry weight decreased by $17.14 \%$ for each unit of EC increase in irrigation water in sandy loam soil. The corresponding values were $4.73 \mathrm{dS} / \mathrm{m}$ and $25.63 \%$ in silt soil. This study indicated that although higher survival rate was observed for Daylily, dry mass production is more sensitive to salinity, which also has been confirmed in Chinese rose (Rosa chinensis) and Sedum spectabile Boreau ( $\mathrm{Li}$ et al. 2015a, b, d). In this study, ridge planting was applied in cultivation of Daylily, and it combined with drip irrigation has been proved effective in salt leaching and improving crop response to salinity (Liu et al., 2012; Wang et al., 2012). So ridge planting method may be one reason that higher survival rates occurred.

\section{Conclusions}

The present study showed that drip-irrigation with saline water worked well in salt leaching in both 
saline-sodic, coastal soils. The very heavy saline soils became mildly or even non-saline soils after 18 months of drip irrigation with water having $\mathrm{EC}_{\mathrm{iw}}$ of 0.8 to $7.8 \mathrm{dS} / \mathrm{m}$. The survival rates were $>93 \%$ when irrigated with saline water at $<7.8 \mathrm{dS} / \mathrm{m}$ in both soils. This study implied that Daylily is suitable in landscape cultivated in coastal saline soil by drip-irrigation with saline water at $\mathrm{EC}_{\mathrm{iw}}<7.8 \mathrm{dS} / \mathrm{m}$, and an SMP above $-5 \mathrm{kPa}$ at $20 \mathrm{~cm}$ depth under the emitter after transplanted and $-10 \mathrm{kPa}$ and $-13 \mathrm{kPa}$ after growing season ended, and $6 \mathrm{~mm}$ of irrigation water can be used as indicators for Daylily drip-irrigation scheduling.

Acknowledgements This study was supported by the National High Technology R\&D Program of China (Grant No. 2013BAC02B02 and 2013BAC02B01) and the National Science Foundation for Young Scientists of China (Grant No. 51409126 and 51509238).

\section{References}

Chen XY, Kang YH, Wan SQ, Chu LL, Li XB (2015) Chinses rose (Rosa chinensis) cultivation in Bohai Bay, China, using an improved drip irrigation method to reclaim heavy coastal saline soils. Agr Water Manage 158: 99-111.

Ding N, Hu L, Zhou RS (2015) The study on the salt tolerance of tissue culture seedings for Daylily. Jiang Su Agr Sci 43(8): 51-52

Dou CY, Kang YH, Wan SQ, Hu W (2011) Soil Salinity Changes Under Cropping with Lycium barbarum L. and Irrigation with Saline-Sodic Water. Pedosphere 21: 539-548

Li X, Kang Y, Wan S, Chen X, Chu L (2015a) Reclamation of very heavy coastal saline soil using drip-irrigation with saline water on salt sensitive plants. Soil Tillage Res 146: 159-173. DOI: 10.1016/j.still.2014.10.005

Li X, Kang Y, Wan S, Chen X, Xu J (2015b) Effect of drip-irrigation with saline water on Chinese rose (Rosa chinensis) during reclamation of very heavy coastal saline soil in a field trial. Sci Hortic 186: 163-171. DOI: 10.1016/j.scienta.2015.02.024

Li X, Kang Y, Wan S, Chen X, Chu L, Xu J (2015c) First and second -year assessments of the rapid reconstruction and re-vegetation method for reclaiming two saline-sodic, coastal soils with drip-irrigation. Ecol. Enq. 84: 496-505.

Li X, Kang Y, Wan S, Chen X, Liu S, Xu J (2015d) A vegetation reconstruction method to plant Sedum spectabile Boreau using drip-irrigation with saline water on a coastal saline soil in region around Bohai Gulf. Paady Water Environ. DOI: 10.1007/s10333-015-0518-7.

Li X, Kang Y, Wan S, Chen X, Liu S, Xu J (2016) Response of a salt-sensitive plant to processes of soil reclamation in two saline-sodic, coastal soils using drip irrigation with saline water. Agr Water Manage. 164: 223-234.

Liu, S, Kang, Y, Wan, S, Wang, Z, Liang, Z, Jiang, S, Wang, R (2012) Germination and growth of Puccinellia tenuiflora in saline-sodic soil under drip irrigation. Agr Water Manage. 109: 127-134.

Mo Y (2011) Cultivation and application of Daylily in landscape gardening. South China Agr. 5(8): 
79-80.

Rhoades JD, Bingham FT, Letey J, Pinter PJ, Lemert RD, Alves WJ, Hoffman GJ, Replogle JA, Swain RV, Pacheco PG (1988) Reuse of drainage water for irrigation-results of imperial-valley study. 2. soil-salinity and water-balance. Hilgardia 56: 17-44.

Rhoades JD, Kandiah A, Mashali AM (1992) The use of saline waters for crop production food and agriculture organization of the United Nations 1-132.

Wang, R, Kang, Y, Wan, S, Hu, W, Liu, S, Jiang, S, Liu, S (2012) Influence of different amounts of irrigation water on salt leaching and cotton growth under drip irrigation in an arid and saline area. Agr Water Manage.110: 109-117. 
Fig. 1 Planting pattern, soil treatment and soil samplings distribution.

Fig. 2 The response of soil $\mathrm{EC}_{\mathrm{e}}$ in 0-35 and 0-95 $\mathrm{cm}$ soil profiles to $\mathrm{EC}_{\mathrm{iw}}$ for sandy loam (a) and silt (b) soils in 2014.11. One-Way ANOVA was conducted to evaluate the effects of $\mathrm{EC}_{\mathrm{iw}}$ on soil $\mathrm{EC}_{\mathrm{e}},{ }^{*} \mathrm{p}<0.05,{ }^{*} \mathrm{p}<0.01$.

Fig. 3 The response of survival rate (SR) of 2014-2015 and shoot dry mass (SDM) of 2014 to EC iw. $_{\text {. }}$ Because the survival rates in silt soil in November, 2014 were all $100 \%$ for the five $\mathrm{EC}_{\mathrm{iw}}$ treatments, the regression line and equation were not shown.

Fig. 4 The response of relative survival rate (RSR) of 2014-2015 and relative dry weight (RDW) of 2014 to $\mathrm{EC}_{\mathrm{iw}}$ One-Way ANOVA was conducted to evaluate the effects of $\mathrm{EC}_{\mathrm{iw}}$ on $\mathrm{RSR}$ and $\mathrm{RDW},{ }^{*} \mathrm{p}<0.05, * * \mathrm{p}<0.01$, $* * * \mathrm{p}<0.001$. 


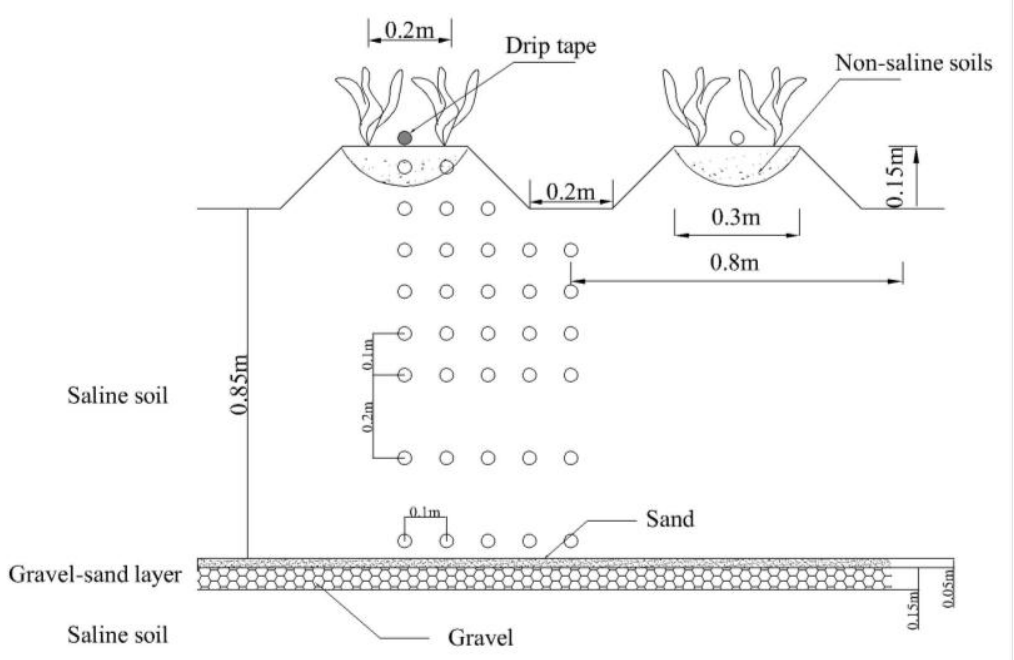

Fig. 1 Planting pattern, soil treatment and soil samplings distribution. 
(a) Sandy loam soil

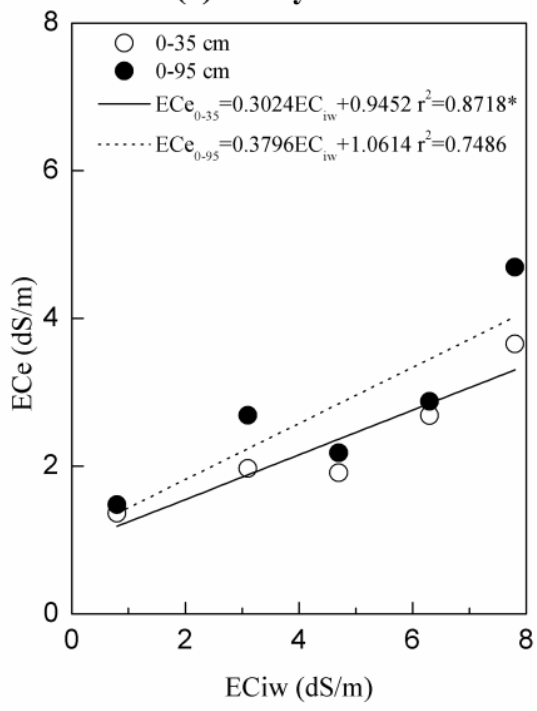

(b) Silt soil

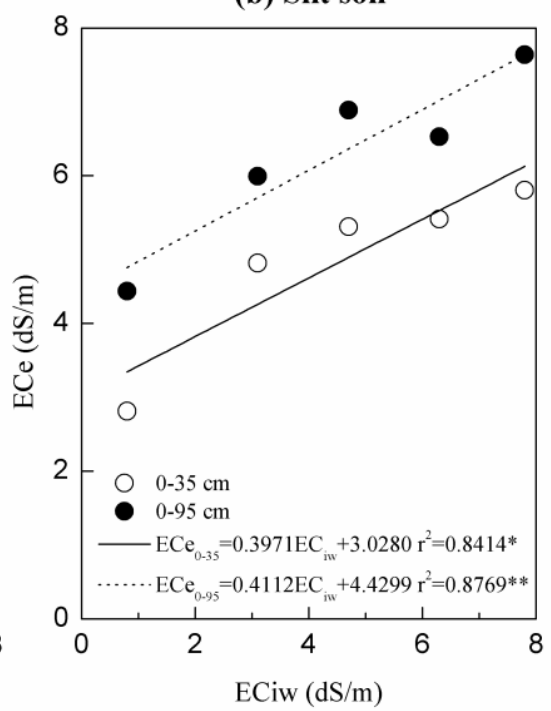

Fig. 2 The response of soil EC $\mathrm{e}$ in 0-35 and 0-95 cm soil profiles to $\mathrm{EC}_{\mathrm{iw}}$ for sandy loam (a) and silt (b) soils in 2014.11. One-Way ANOVA was conducted to evaluate the effects of $\mathrm{EC}_{\mathrm{iw}}$ on soil $\mathrm{EC}$ e, ${ }^{*} \mathrm{p}<0.05,{ }^{* *} \mathrm{p}<0.01$. 

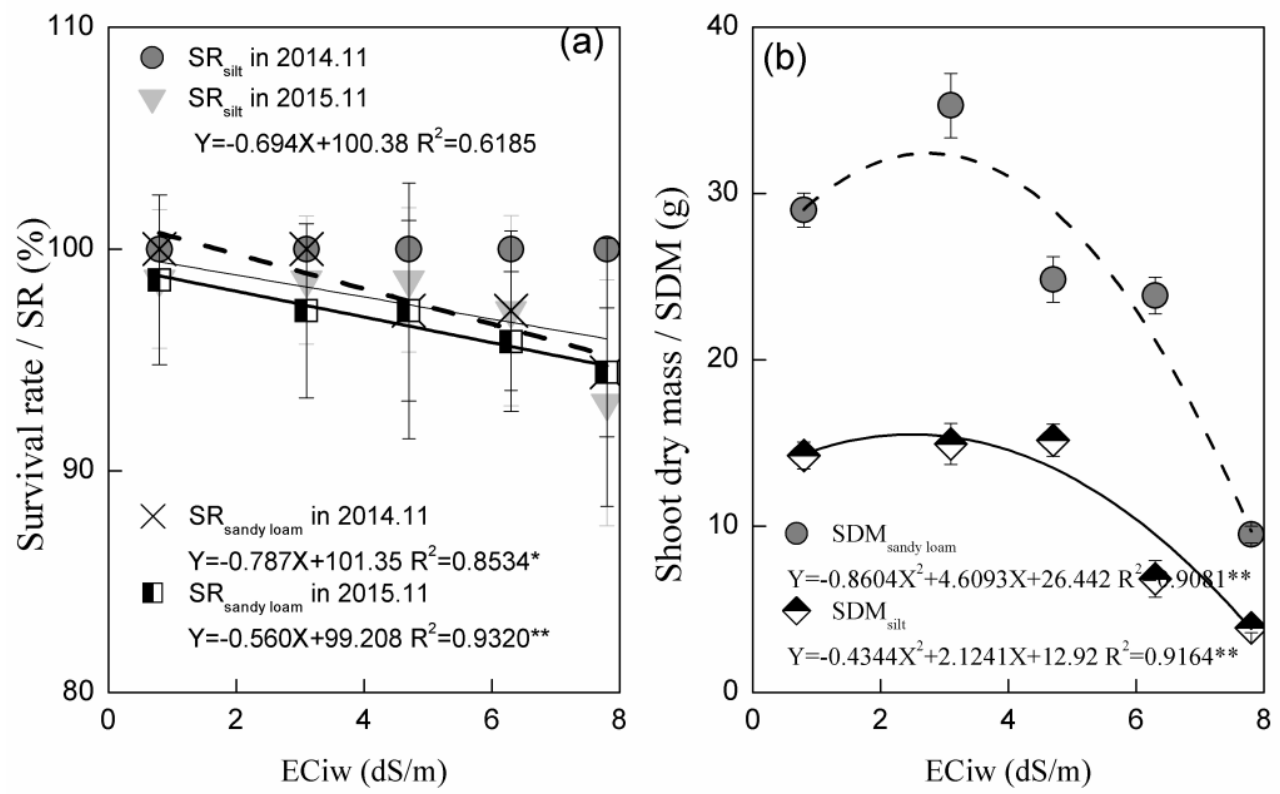

Fig. 3 The response of survival rate (SR) of 2014-2015 and shoot dry mass (SDM) of 2014 to $\mathrm{EC}_{\text {iw }}$. Because the survival rates in silt soil in November, 2014 were all $100 \%$ for the five $\mathrm{EC}_{\mathrm{iw}}$ treatments, the regression line and equation were not shown. 
(a) Sandy loam soil

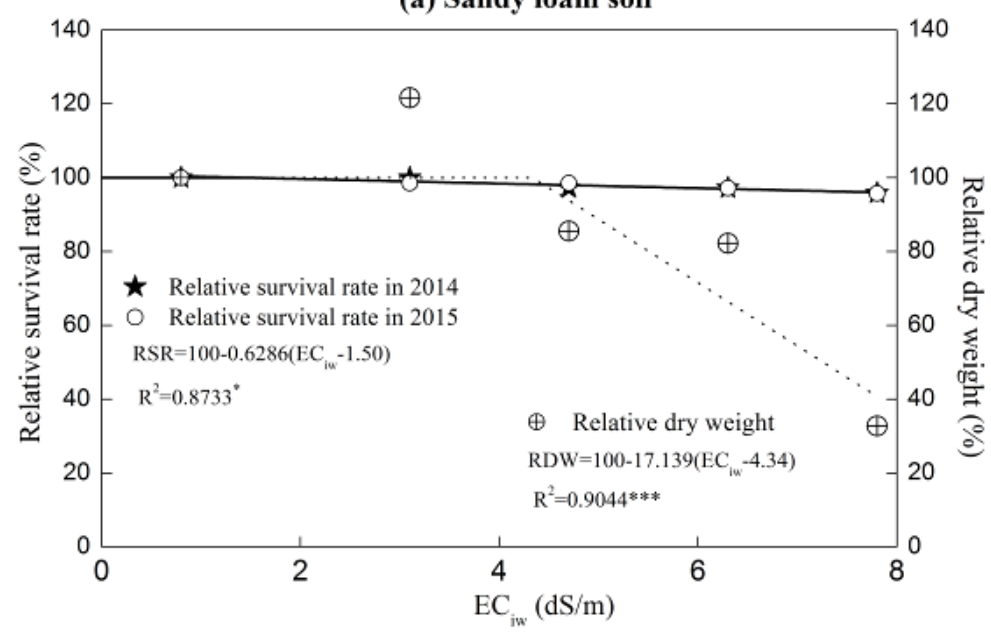

(b) Silt soil

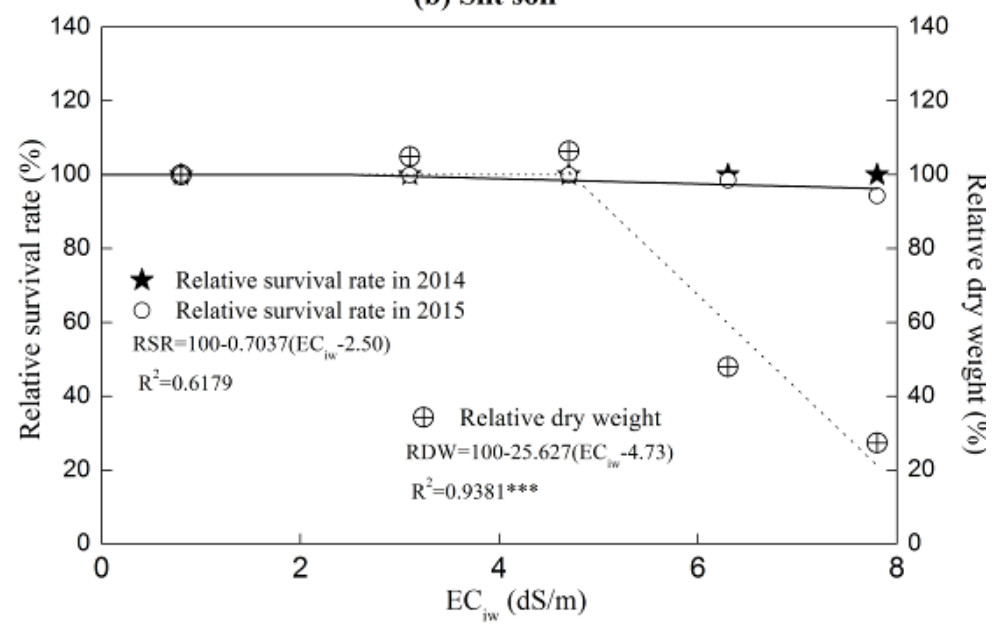

Fig. 4 The response of relative survival rate (RSR) of 2014-2015 and relative dry weight (RDW) of 2014 to $\mathrm{EC}_{\mathrm{iw}}$. One-Way ANOVA was conducted to evaluate the effects of $\mathrm{EC}_{\mathrm{iw}}$ on soil RSR and RDW, ${ }^{*} p<0.05, * * \mathrm{p}<0.01, * * *_{\mathrm{p}}<0.001$. 
Table 1 Soil mechanical composition, bulk density, $\mathrm{EC}_{\mathrm{e}}$ (electrical conductivity of saturated paste extracts), $\mathrm{pHs}$ ( $\mathrm{pH}$ of saturated paste) and SAR (sodium adsorption rate of saturated paste extracts) in initial soils

\begin{tabular}{|c|c|c|c|c|c|c|c|c|c|}
\hline \multirow[t]{2}{*}{ Site } & \multirow{2}{*}{$\begin{array}{l}\text { Soil } \\
\text { depth } \\
(\mathrm{cm})\end{array}$} & \multicolumn{3}{|c|}{ Soil mechanical composition (\%) } & \multirow{2}{*}{$\begin{array}{l}\text { Soil } \\
\text { texture }\end{array}$} & \multirow{2}{*}{$\begin{array}{l}\text { Bulk } \\
\text { density } \\
\left(\mathrm{g} / \mathrm{cm}^{3}\right)\end{array}$} & \multirow{2}{*}{$\begin{array}{l}\mathrm{EC}_{\mathrm{e}} \\
(\mathrm{dS} / \mathrm{m})\end{array}$} & \multirow[t]{2}{*}{$\mathrm{pHs}$} & \multirow{2}{*}{$\begin{array}{l}\text { SAR } \\
(\mathrm{mmol} / \mathrm{L})^{0.5}\end{array}$} \\
\hline & & $\begin{array}{l}<0.002 \\
\mathrm{~mm}\end{array}$ & $\begin{array}{l}0.002-0.05 \\
\mathrm{~mm}\end{array}$ & $\begin{array}{l}0.05-2 \\
\mathrm{~mm}\end{array}$ & & & & & \\
\hline \multirow{3}{*}{ Eco-City } & $0-25$ & 0.48 & 42.89 & 56.63 & \multirow{3}{*}{$\begin{array}{l}\text { Sandy } \\
\text { loam }\end{array}$} & 1.35 & 27.73 & 7.97 & 54.38 \\
\hline & $25-45$ & 0.52 & 41.66 & 57.83 & & 1.57 & 28.03 & 8.06 & 55.28 \\
\hline & $45-95$ & 0.55 & 45.36 & 54.09 & & 1.69 & 27.31 & 7.88 & 50.28 \\
\hline \multirow{3}{*}{$\begin{array}{c}\text { Industrial } \\
\text { area }\end{array}$} & $0-25$ & 0.94 & 80.71 & 18.35 & \multirow{3}{*}{ Silt } & 1.48 & 29.30 & 7.91 & 56.45 \\
\hline & $25-45$ & 0.90 & 82.80 & 16.30 & & 1.66 & 27.66 & 8.08 & 57.43 \\
\hline & $45-95$ & 1.16 & 82.64 & 16.20 & & 1.68 & 27.08 & 8.03 & 58.30 \\
\hline
\end{tabular}


Table 2 Amount of rainfall and irrigation water $(\mathrm{mm})$ for each treatment in 2013 2015.

\begin{tabular}{|c|c|c|c|c|c|c|c|c|c|c|c|}
\hline \multirow{3}{*}{$\begin{array}{l}\text { Soil } \\
\text { type }\end{array}$} & \multirow{3}{*}{$\begin{array}{c}\mathrm{EC}_{\mathrm{iw}} \\
(\mathrm{dS} / \mathrm{m})\end{array}$} & \multicolumn{10}{|c|}{ Time } \\
\hline & & \multicolumn{5}{|c|}{ Rainfall (mm) } & \multicolumn{5}{|c|}{ Irrigation water depth (mm) } \\
\hline & & $\begin{array}{c}2013 \\
\text { (Jun/Jul- } \\
\text { Nov) }\end{array}$ & $\begin{array}{c}2014 \\
\text { (Jun/Jul- } \\
\text { Nov) }\end{array}$ & $\begin{array}{l}2014 \\
\text { (Apr- } \\
\text { Nov) }\end{array}$ & $\begin{array}{c}2015 \\
\text { (Jun/Jul- } \\
\text { Nov) }\end{array}$ & $\begin{array}{l}2015 \\
\text { (Apr- } \\
\text { Nov) }\end{array}$ & $\begin{array}{c}2013 \\
\text { (Jun/Jul- } \\
\text { Nov) }\end{array}$ & $\begin{array}{c}2014 \\
\text { (Jun/Jul- } \\
\text { Nov) }\end{array}$ & $\begin{array}{l}2014 \\
\text { (Apr- } \\
\text { Nov) }\end{array}$ & $\begin{array}{c}2015 \\
\text { (Jun/Jul- } \\
\text { Nov) }\end{array}$ & $\begin{array}{l}2015 \\
\text { (Apr- } \\
\text { Nov) }\end{array}$ \\
\hline \multirow{6}{*}{ Silt } & 0.8 & \multirow{6}{*}{434} & \multirow{6}{*}{400} & \multirow{6}{*}{450} & \multirow{6}{*}{309} & \multirow{6}{*}{370} & 366 & 324 & 504 & 258 & 354 \\
\hline & 3.1 & & & & & & 384 & 384 & 570 & 324 & 396 \\
\hline & 4.7 & & & & & & 276 & 252 & 390 & 222 & 288 \\
\hline & 6.3 & & & & & & 312 & 372 & 558 & 270 & 378 \\
\hline & 7.8 & & & & & & 294 & 276 & 426 & 234 & 312 \\
\hline & Average & & & & & & 326 & 322 & 490 & 262 & 346 \\
\hline \multirow{6}{*}{$\begin{array}{l}\text { Sandy } \\
\text { loam }\end{array}$} & 0.8 & \multirow{6}{*}{410} & \multirow{6}{*}{329} & \multirow{6}{*}{416} & \multirow{6}{*}{395} & \multirow{6}{*}{565} & 210 & 114 & 342 & 72 & 168 \\
\hline & 3.1 & & & & & & 264 & 138 & 318 & 84 & 204 \\
\hline & 4.7 & & & & & & 246 & 72 & 240 & 66 & 132 \\
\hline & 6.3 & & & & & & 372 & 120 & 318 & 108 & 216 \\
\hline & 7.8 & & & & & & 348 & 186 & 384 & 54 & 186 \\
\hline & Average & & & & & & 288 & 126 & 320 & 77 & 181 \\
\hline
\end{tabular}


Table 3 Daylily growth characteristics for different irrigation water qualities $\left(\mathrm{EC}_{\mathrm{iw}}\right)$ in 2014-2015

\begin{tabular}{ccccccc}
\hline \multirow{2}{*}{ Treatments } & \multicolumn{3}{c}{ Survival rate (\%) } & \multicolumn{3}{c}{ Shoot dry mass $(\mathrm{g})$} \\
\cline { 2 - 7 } & \multicolumn{2}{c}{ Sandy loam } & \multicolumn{2}{c}{ Silt } & \multicolumn{2}{c}{2014.11} \\
\cline { 2 - 7 } & 2014.11 & 2015.11 & 2014.11 & 2015.11 & Sandy loam & Silt \\
\hline $0.8 \mathrm{dS} / \mathrm{m}$ & $100.00 \mathrm{a}$ & $98.61 \mathrm{a}$ & $100.00 \mathrm{a}$ & $98.65 \mathrm{a}$ & $29.02 \mathrm{a}$ & $14.25 \mathrm{a}$ \\
$3.1 \mathrm{dS} / \mathrm{m}$ & $100.00 \mathrm{a}$ & $97.22 \mathrm{ab}$ & $100.00 \mathrm{a}$ & $98.61 \mathrm{a}$ & $35.30 \mathrm{a}$ & $14.95 \mathrm{a}$ \\
$4.7 \mathrm{dS} / \mathrm{m}$ & $97.22 \mathrm{~b}$ & $97.22 \mathrm{ab}$ & $100.00 \mathrm{a}$ & $98.61 \mathrm{a}$ & $24.83 \mathrm{ab}$ & $15.17 \mathrm{a}$ \\
$6.3 \mathrm{dS} / \mathrm{m}$ & $97.22 \mathrm{~b}$ & $95.83 \mathrm{~b}$ & $100.00 \mathrm{a}$ & $97.22 \mathrm{a}$ & $23.87 \mathrm{ab}$ & $6.83 \mathrm{ab}$ \\
$7.8 \mathrm{dS} / \mathrm{m}$ & $94.44 \mathrm{~b}$ & $94.44 \mathrm{~b}$ & $100.00 \mathrm{a}$ & $93.06 \mathrm{~b}$ & $9.50 \mathrm{~b}$ & $3.90 \mathrm{~b}$ \\
Average & 98.06 & 96.67 & 100.00 & 97.23 & 24.50 & 11.02 \\
\hline
\end{tabular}

Note: One-Way ANOVA was conducted to evaluate the effects of $\mathrm{EC}_{\mathrm{iw}}$ on survival rate and shoot dry mass. Values followed by different letters within the same year in column differ significantly at $p<0.05$ 